\title{
Methods to determine drainage area in shale formations produced by stimulated horizontal wells using reservoir simulation modelling
}

\begin{abstract}
The paper presents an analysis of the drainage area generated by a single horizontal production well completed in shale gas formations. The analysis was performed with the use of numerical simulation models of the formations and stimulated wells with parameters in the range found in Polish formations and the wells drilled in them. Practical definitions of the drainage area were proposed. Their sizes and some other characteristics were studied for their dependence upon the reservoir parameters and completion characteristics.
\end{abstract}

Key words: shale formations, drainage area, reservoir simulation models.

\section{Metodyka wyznaczenia wielkości obszaru drenażu w formacjach łupkowych przy pomocy złożowych modeli symulacyjnych}

W pracy przeprowadzono analizę wielkości obszaru drenażu pojedynczego odwiertu horyzontalnego udostępniającego formację łupkową nasyconą gazem. Analizę tą przeprowadzono przy pomocy symulacyjnych modeli złożowych o parametrach złożowych i charakterystykach udostępnienia obejmujących wartości typowe dla formacji krajowych. Zaproponowano praktyczne definicje wielkości obszaru drenażu i zbadano jej zależność od wartości głównych parametrów złożowych formacji i parametrów ich udostępnienia.

Słowa kluczowe: formacje łupkowe, obszar drenażu, symulacyjne modele złożowe.

\section{Introduction}

The determination of production well spacing is one of the basic problems of hydrocarbon reservoirs' development optimisation $[3,17,19]$. It is particularly important in the situation of unconventional reservoirs, such as shale formations, for which the process of drainage is of transient type throughout the entire period of production. Contrary to conventional reservoirs, for which the reservoir breakdown into drainage zones of individual wells is determined in a very short time after a change in extraction conditions (well numbers and location, their production rates), this fact, combined with low drainage effectiveness, means that proper development of an unconventional reservoir can decide the economic viability of the considered formation production $[1,2,4-7,10,11,15$, $18,20]$. In terms of recovery effectiveness, unconventional reservoirs (shale gas [12], tight gas [14] and other formations), to a much larger degree than conventional reservoirs, depend on: (i) geological-petrophysical parameters, including systems of multiple porosity and permeability characterized by large variation of their values, (ii) the method of completion borehole stimulation in those formations is indispensable to obtain even a minimum output. Therefore the analysis of the size and effectiveness of the recovery of wells' drainage areas in such reservoirs is a very complex issue and cannot only rely on the measurement data, which is necessarily limited in domestic practice. Hence, a need originates to apply simulation reservoir models that ensure the possibility of analysing a broad spectrum of both reservoir conditions (geological parameters) and of completion methods for unconventional reservoirs. The reservoir simulations were carried out using the Eclipse simulator [13]. 


\section{Shale formations simulation models}

Synthetic models of shale formations and methods for their completion were constructed. The general structure of such models was implemented in the form of the diagram presented in Figure 1 [16]. These models describe the drainage zone of a single horizontal well, which was subject to stimulation treatments in the form of multiple hydraulic fracturing causing the origination of a (regular) system of hydraulic fractures and generating the activation of secondary fractures creating the system of Stimulated Reservoir Volume (SRV) [9]. The remaining reservoir volume was marked as XRV (External Rock Volume - Fig. 2). Hydraulic fractures [8] were modelled in the form of discrete objects. The system of active secondary fractures was modelled by a system of multiple porosity. A constant reservoir thickness and height of the fractured area was assumed. A widely used description of shale formations was applied, in which the primary fractures are ineffective and are activated as a result of stimulation in the SRV area. Therefore the SRV area was modelled as a double porosity area.

The presence of gas consisting of $100 \%$ methane and water of standard properties was assumed in the models. Water was an immobile phase in the considered models. As a result, the effective porosity was taken as entirely gas saturated. The pressure $P_{\text {res, }, i n i}=310$ bars and the temperature $T_{\text {res }}=100^{\circ} \mathrm{C}$ were assumed as the initial reservoir conditions.

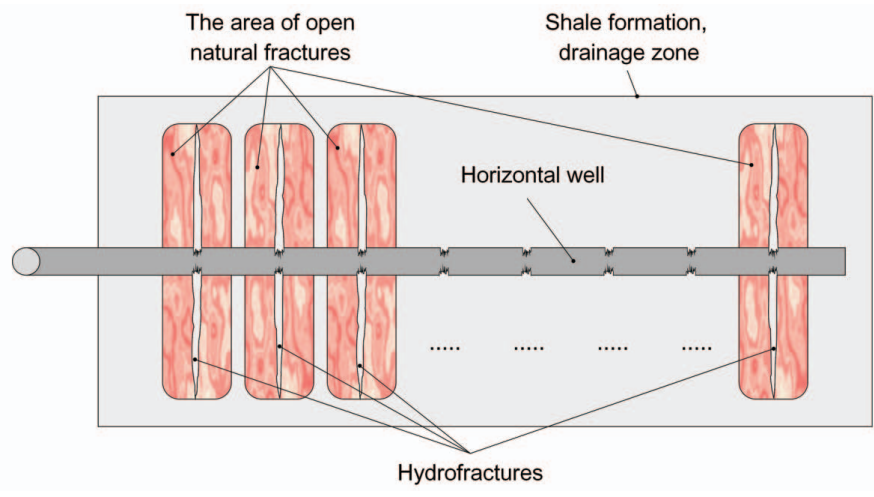

Fig. 1. The structure of shale formation development model. Top view

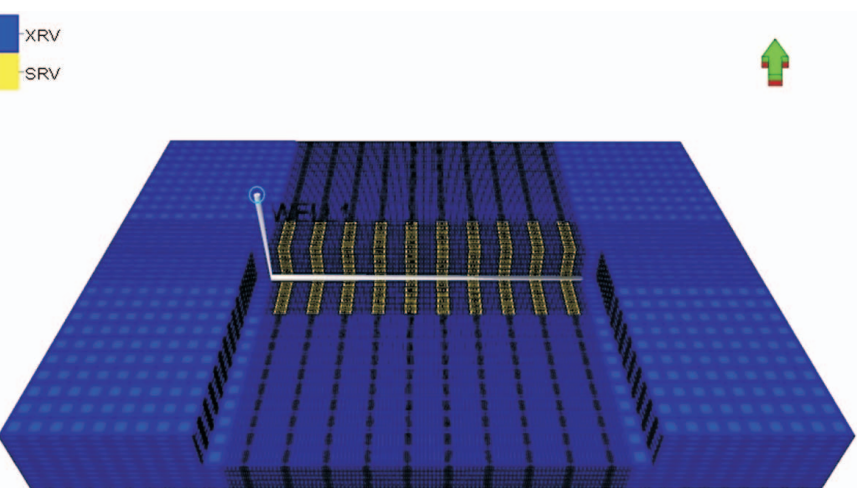

Fig. 2. The structure of shale formation simulation model. SRV and XRV areas

\section{Models parameters}

The following first set of data describing the reservoir and completion parameters was taken for these models.

Reservoir parameters:

- effective matrix porosity (saturated with gas): $\phi_{m}=4.76 \%$,

- fractures porosity: $\phi_{f}=3.08 \%$,

- matrix permeability in the SRV and XRV areas: $k_{m}=10 \div 1000 \mathrm{nD}$,

- fractures permeability in the SRV area: $k_{f}=0.1 \div 10 \mathrm{mD}$,

- the matrix-fractures coupling coefficient: $\sigma=0.05 \mathrm{~m}^{-2}$,

- the gas desorption (Langmuir isotherm) parameters:

- Langmuir volume: $V_{L}=0.0,6.0 \mathrm{Nm}^{3} / \mathrm{t}(0 \%, 50 \%$ of resources - values of adsorption parameters were taken for extreme situations),

- Langmuir pressure: $P_{L}=30$ bars,
- diffusivity: $D=0.0059 \mathrm{~m}^{2} / \mathrm{d}$.

Completion parameters:

- well horizontal section length: $L_{h}=776 \mathrm{~m}$,

- number of fracturing sections: $n_{f}=4,8,16$,

- length of the fractured area: $l_{f}=250 \div 550 \mathrm{~m}$,

- width of the fractured area: $d_{f}=2 \div 122 \mathrm{~m}$,

- hydrofracture transmissibility: $T_{f h}=200 \mathrm{mD} \times \mathrm{m}$,

- bottom hole pressure: $P_{b h p}=35$ bars.

A constant irreducible water saturation was assumed, $S_{\text {wir }}=20 \%$.

The structure of double porosity (fracture + matrix) and of single permeability (only fractures) in the SRV area, and of standard single porosity and permeability (matrix only) in the XRV area were assumed.

\section{Production conditions}

The control of production by the fixed bottom hole pressure was assumed as $P_{b h p}=35$ bars. The following conditions were assumed for production termination: (a) maximum period of time: $t_{f}=30$ years, (b) minimum rate: $q_{g}=1 \mathrm{SCm}^{3} / \mathrm{min}$ $\left(1440 \mathrm{SCm}^{3} / \mathrm{d}\right)$. The effective condition was considered the one that occurred sooner. 


\section{Definition of the drainage zone size}

The drainage zone of a single producing well was defined in two ways:

1) via the boundary of production disturbances,

2) via the minimum average recovery coefficient.

The first of the two methods consisted in the determination of the total production $G_{p}$ as a function of the model area size $A_{\text {model }}$ (Fig. 3). For small model sizes one straight line has been fitted, while for large models a second straight line has been fitted, and the intersection of the determined straight lines projected on the horizontal axis determines the drainage zone $A_{\text {drain }}$.

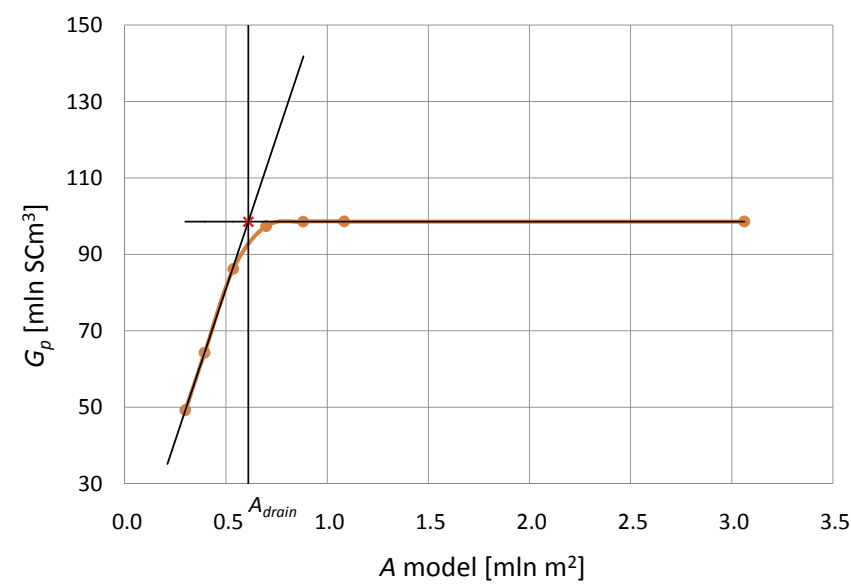

Fig. 3. Determination of the drainage zone via the relationship between the total production and the model size

A rectilinear relationship between the gas total production $G_{p}$ and the model area size $A$ was found, for small and large $A$ values (Fig. 3), which allowed a clear and effective specification of the intersection point as the method for the drainage area $A_{\text {drain }}$ determination.
Attention should be drawn to the fact of the external boundary application when defining the model size. The drainage area may not be basically compact (may include internal undrained elements). However, such a situation has no direct importance in the practical use of this analysis to determine the production well spacing.

The average recovery coefficient of the XRV (drained part) area depending on this area size was determined in the alternative method (Fig. 4), which allowed the definition of the size of the drainage area for the assumed limiting recovery coefficient-within XRV, as a sum of the SRV area and the XRV part defined in this way. The following example shows the methodology for determination of the drainage area size for the given recovery coefficient, which utilises the curve of the average recovery coefficient of XRV area depending on the model size.

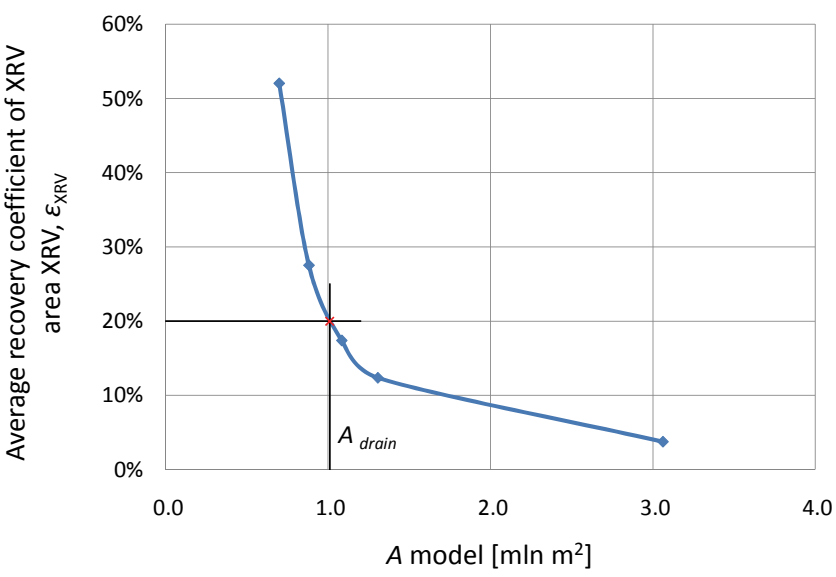

Fig. 4. Determination of the drainage zone via the relationship between the average recovery coefficient of the XRV area and the model size

\section{Analysis of the drainage zone size}

The drainage zone size for variable reservoir and completion parameters was analysed for the first of the above definitions, in the following ranges of the parameters:

- matrix permeabilities in the SRV and XRV areas: $k_{m}=10$, $100,250,500,750,1000 \mathrm{nD}$,

- fractures permeabilities in the SRV areas: $k_{f}=0.087$, $0.87,8.7 \mathrm{mD}$,

- SRV area widths around each hydrofracture: $d_{f}=2,22$, $42,62,122 \mathrm{~m}$,

- length of the fractured area: $l_{f}=250,350,450,550 \mathrm{~m}$,

- presence/absence of the adsorbed gas.

The remaining parameters were determined for the previously given values.
A strong dependence of the drainage zone size on the matrix permeability $k_{m}$ was confirmed both for the case without the adsorbed gas shown in Figure 5 and for the case with the gas desorption presented in Figure 6.

The results show that:

- the drainage area substantially exceeds the SRV area,

- this area depends significantly on the matrix permeability,

- its dependence on the fractures permeability in the SRV area is less significant,

- the presence of the adsorbed gas reduces the effective size of the drainage area.

The drainage area defined above shows a much more complicated dependence on the width $d_{f}$ of SRV areas in individual 
fracturing sections. With increasing SRV resulting from the increase in $d_{f}$ initially a linear increase in the gas production total is observed (due to no interference of individual areas in each section), and then the effect of saturation appears (Fig. 7) caused by partial overlapping of those areas.

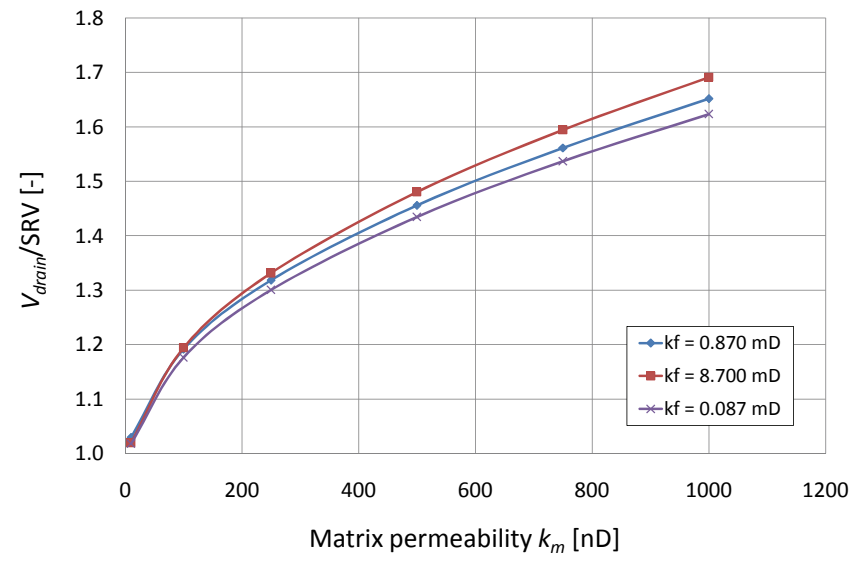

Fig. 5. The relationship between the drainage area size $V_{\text {drain }}$ (expressed as the ratio: $V_{\text {drain }} / \mathrm{SRV}$ ) and the matrix permeability $k_{m}$ for various fracture permeabilities $k_{f}$ (cases without desorption)

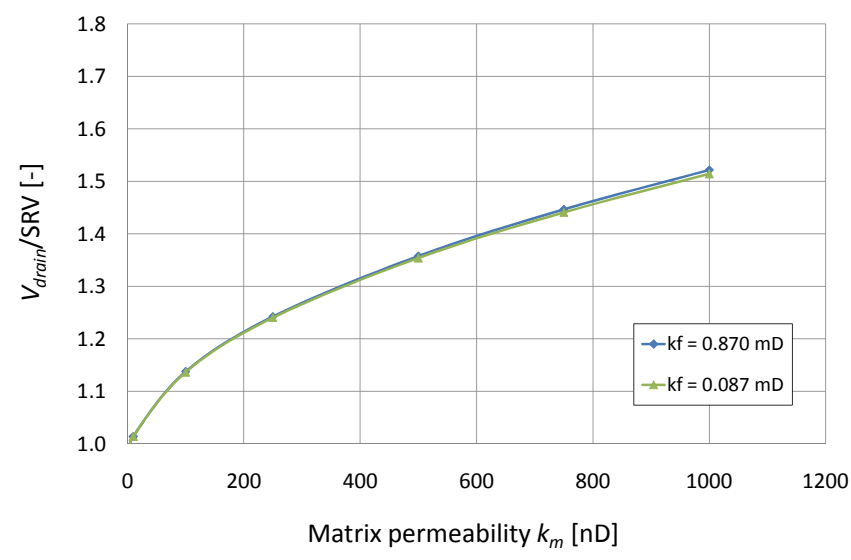

Fig. 6. The relationship between the drainage area size $V_{\text {drain }}$ (expressed as the ratio: $V_{\text {drain }} / \mathrm{SRV}$ ) and the matrix permeability $k_{m}$ for various fracture permeabilities $k_{f}$ (cases with desorption)

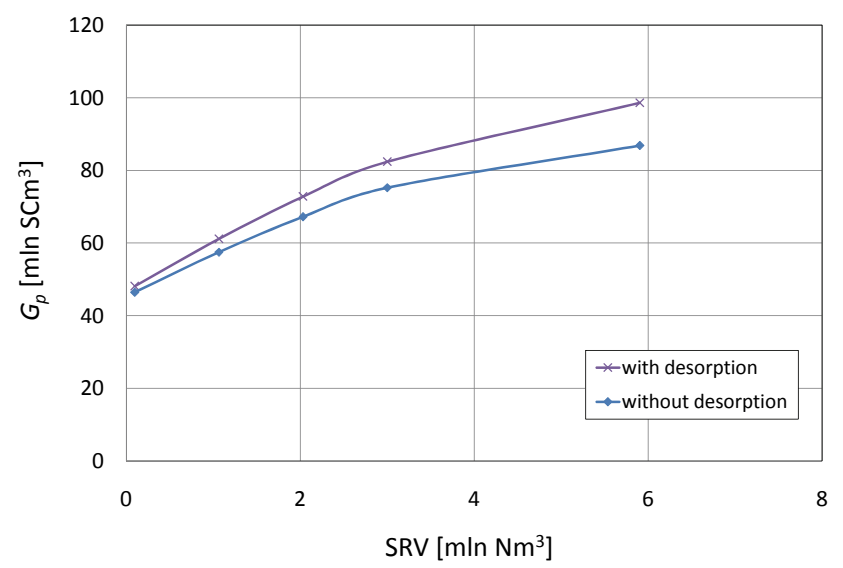

Fig. 7. The relationship between the production total $G_{p}$ and the volume of SRV modified by $d_{f}$

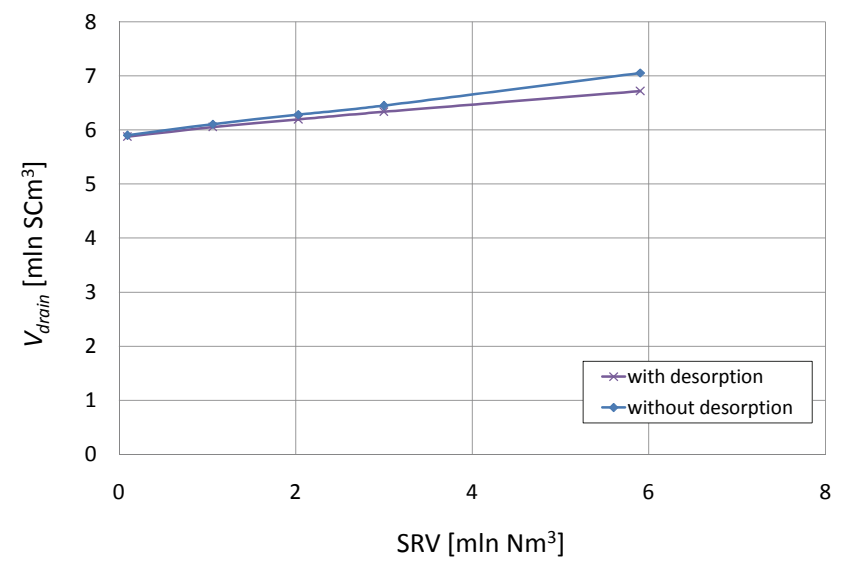

Fig. 8. The relationship between the drainage volume $V_{\text {drain }}$ and the volume of SRV modified by $d_{f}$

As a result, the drainage area defined by the external boundary only slightly depends on the width $d_{f}$ (Fig. 8), i.e. an increase in the SRV areas width in each section has a small (disproportionate) impact on the effective (external) drainage area. The influence of the length of the SRV area (length of hydrofractures $l_{f}$ ) on the drainage area size is different. A roughly proportional growth of this magnitude is observed, i.e. the $V_{\text {drain }} / \mathrm{SRV}$ ratio is practically independent of the length of hydrofractures $l_{f}$ (Fig. 9).

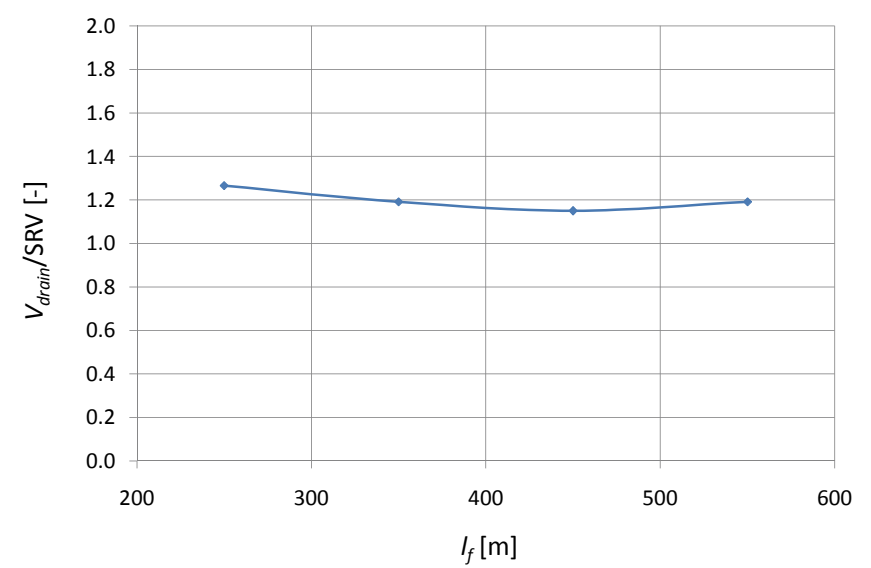

Fig. 9. The relationship between the drainage volume $V_{\text {drain }}$ and the length of fractures $l_{f}$ (cases without desorption)

The reservoir completion via additional fractures, assuming a constant size of the SRV area, does not result in a significant increase in the drainage area (Fig. 10). However, the fact that a smaller number of fracturing treatments usually means a smaller SRV area should be considered.

The analysis of SRV and XRV (in the part covered by the drainage) areas recovery coefficients was performed for the analysed model, which resulted in a constant value of the recovery coefficient (approx. 87\%) independent of the matrix permeability for the SRV area. For the XRV area, within the matrix permeability from 100 to $1000 \mathrm{nD}$, a nearly constant 


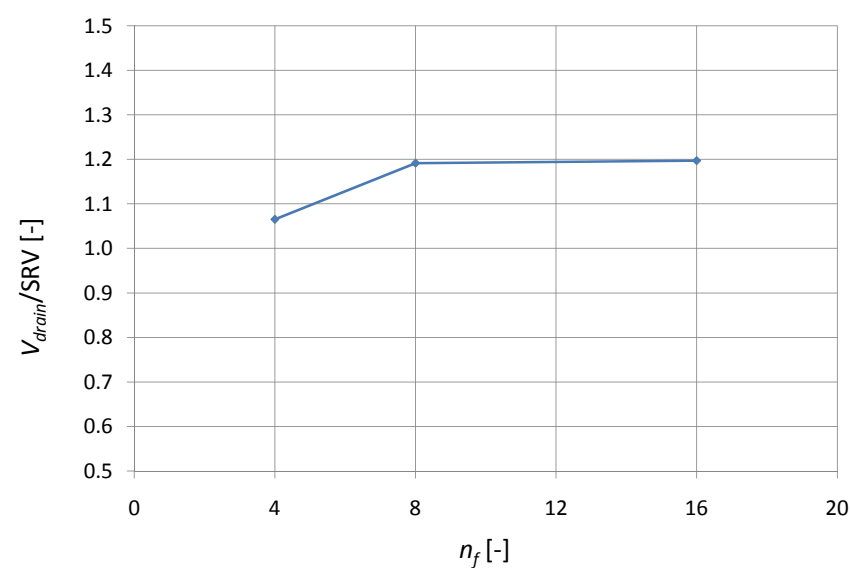

Fig. 10. The relationship between the drainage volume $V_{\text {drain }}$ and the number of fracturing sections (cases without desorption)

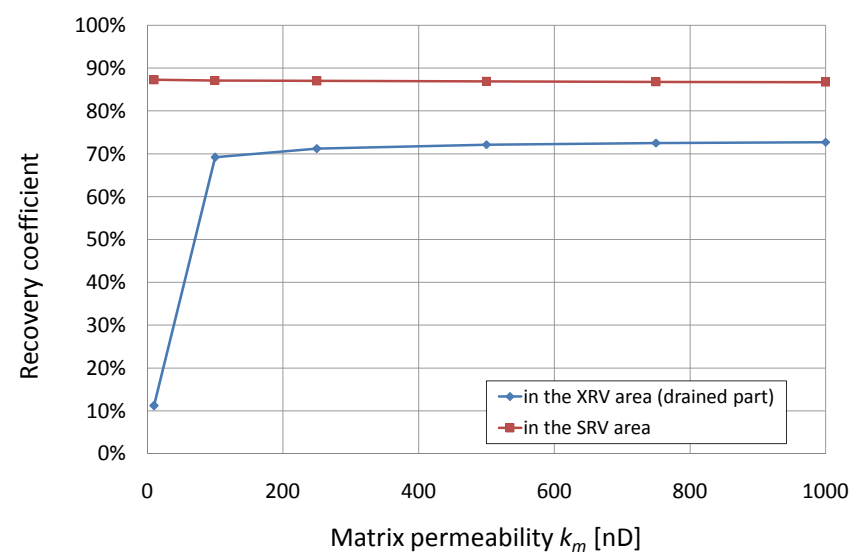

Fig. 11. The average recovery coefficient in the drainage area vs. the matrix permeability $k_{m}$ for the fractures permeability $k_{f}$ from the $0.1 \div 10 \mathrm{mD}$ range recovery coefficient was also obtained, around $72 \%$. This coefficient had a smaller value of $11 \%$ only for the matrix permeability of $10 \mathrm{nD}$ (Fig. 1). The lack of the recovery coefficient dependence on the matrix permeability in the drained $\mathrm{XRV}$ area occurs together with the increase in the drainage area size for growing matrix permeabilities. Figure 12 illustrates the latter relationship, showing the drainage area size vs. the matrix permeability for a fixed average recovery coefficient in the XRV area.

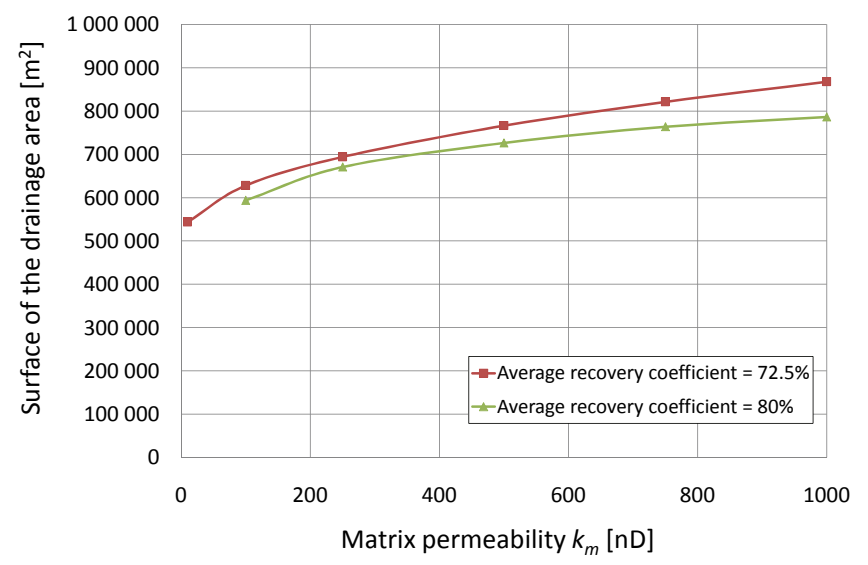

Fig. 12. The size of the drainage area with a fixed average recovery coefficient (in the drained part of XRV) vs. the matrix permeability

\section{Summary}

The paper presents an analysis of the drainage area size in shale formations using single-phase simulation reservoir models for such formations. The definition of the drainage area size was assumed as the basic value used to determine the production well spacing. The relationship was studied between the drainage area and (i) a group of parameters describing the reservoir properties of shale formations, (ii) parameters characterising the method and effectiveness of those formations completion by a fractured horizontal well. The possibility of the occurrence of the drainage area $\left(V_{\text {drain }}\right)$ clearly enlarged (up to $170 \%$ ) as against the fracturing area (SRV) was found, where the non-fractured part (XRV) can reach a significant degree of recovery. A significant relationship between $V_{\text {drain }} / \mathrm{SRV}$ and the matrix permeability was found at a clearly smaller dependence on secondary fractures permeability. In addition, the presence of adsorbed gas limits the drainage area size. A proportionality between the drainage area and the SRV area size was confirmed. It should be emphasised that the above conclusions refer to the drainage area size and not to the gas production total from the shale formations, which through the factor of production time may result, in the case of this time being reduced, in the need to apply reduced drainage areas.

Please cite as: Nafta-Gaz 2015, no. 12, pp. 992-997, DOI: 10.18668/NG2015.12.07

Article contributed to the Editors 31 August 2015. Approved for publication 27 October 2015

The article is the result of research conducted in connection with a project: Development of optimum concepts for unconventional deposits management, considering environmental and social aspects, co-funded by the National Centre for Research and Development as part of the programme BLUE GAS - POLISH SHALE GAS. Contract No. BG1/ResDev/13. 


\section{Literature}

[1] Cheng Y., McVay D. A., Ayers W. B. et al.: Simulation-Based Technology for Rapid Assessment of Redevelopment Potential in Marginal Gas Fields - Technology Advances and Validation in Garden Plains Field, Western Canada Sedimentary Basin. SPE Reservoir Evaluation \& Engineering 2008, 11 (3), pp. 521-534. SPE-100583-PA. DOI: 10.2118/100583-PA.

[2] Cheng Y., McVay D. A., Wang J. et al.: Simulation-Based Technology for Rapid Assessment of Redevelopment Potential in Stripper-Gas-Well Fields - Technology Advances and Validation in the Garden Plains Field, Western Canada Sedimentary Basin. Paper SPE 100583 presented at the SPE Gas Technology Symposium, Calgary, Alberta 15-17 May 2006. DOI: 10.2118/100583-MS.

[3] Corrie R. D.: An Analytical Solution to Estimate the Optimum Number of Development Wells to Achieve Maximum Economical Return. Society of Petroleum Engineers 2001. DOI: 10.2118/71431-MS.

[4] Gao H., McVay D. A.: Gas Infill Well Selection Using Rapid Inversion Methods. Paper SPE 90545 presented at the SPE Annual Technical Conference and Exhibition, Houston, Texas 26-29 September 2004. DOI: 10.2118/90545-MS.

[5] Guan L., Du Y.: Fast Method Finds Infill Drilling Potentials in Mature-Tight Reservoirs. Paper SPE 91755 presented at the SPE International Petroleum Conference in Mexico, Puebla 7-9 November 2004. DOI: 10.2118/91755-MS

[6] Guan L., McVay D. A., Jensen J. L. et al.: Evaluation of a Statistical Infill Candidate Selection Technique. Paper SPE 75718 presented at the SPE Gas Technology Symposium, Calgary, Alberta 30 April - 2 May 2002. DOI: 10.2118/75718-MS.

[7] Hudson J. W., Jochen J. E., Spivey J. P.: Practical Methods to High-Grade Infill Opportunities Applied to the Mesaverde, Morrow, and Cotton Valley Formations. Paper SPE 68598 presented at the SPE Hydrocarbon Economics and Evaluation Symposium, Dallas 2-3 April 2001. DOI: 10.2118/68598-MS.

[8] Kasza P.: Zabiegi hydraulicznego szczelinowania $w$ formacjach lupkowych. Nafta-Gaz 2011, no. 12, pp. 874-883.

[9] Mayerhofer M. J., Lolon E., Warpinski N. R., Cioplla C. L., Walser D. W., Rightmire C. M.: What Is Stimulated Reservoir Volume? Society of Petroleum Engineers 2010. SPE-119890-PA.

[10] McCain W. D., Voneiff G. W., Hunt E. R. et al.: A Tight Gas Field Study: Carthage (Cotton Valley) Field. Paper SPE 26141

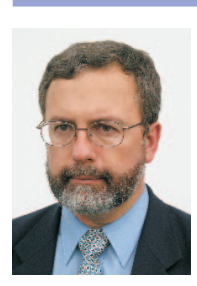

Dr. Wiesław SZOTT PhD.

Assistant Professor

Head of the Department of Hydrocarbon Deposits and UGS Facilities Simulation

Oil and Gas Institute - National Research Institute

ul. Lubicz 25 A, 31-503 Kraków

E-mail: wieslaw.szott@inig.pl presented at the SPE Gas Technology Symposium, Calgary, Alberta 28-30 June 1993. DOI: 10.2118/26141-MS.

[11] Newsham K. E., Rushing J. A.: An Integrated Work-Flow Model to Characterize Unconventional Gas Resources: Part I - Geological Assessment and Petrophysical Evaluation. Paper SPE 71351 presented at the SPE Annual Technical Conference and Exhibition, New Orleans, Louisiana 30 September - 3 October 2001. DOI: 10.2118/71351-MS.

[12] Praca zbiorowa. Rzeczpospolita lupkowa. Studium wiedzy o gazie z formacji lupkowych. Prace Naukowe INiG 2012, no. $183,310 \mathrm{pp}$.

[13] Pakiet Eclipse 300, Release 2010.1, 2014.1 firmy GeoQuest, Schlumberger.

[14] Prognostyczne zasoby gazu ziemnego w wybranych zwięzlych skalach zbiornikowych Polski. Raport PIG - PIB, Warszawa 2014.

[15] Rushing J. A., Newsham K. E.: An Integrated Work-Flow Model to Characterize Unconventional Gas Resources: Part IIFormation Evaluation and Reservoir Modeling. Paper SPE 71352 presented at the SPE Annual Technical Conference and Exhibition, New Orleans, Louisiana 30 September - 3 October 2001. DOI: 10.2118/71352-MS.

[16] Szott W., Golabek A: Symulacje procesu eksploatacji zloz gazu ziemnego w formacjach lupkowych (shale gas). Nafta-Gaz 2012, no. 12, pp. 923-936.

[17] Tabatabaei Nejad S. A., Aleagha A. A. V., Salari S.: Estimating Optimum Well Spacing in a Middle East Onshore Oil Field Using a Genetic Algorithm Optimization Approach. Society of Petroleum Engineers 2007. DOI: 10.2118/105230-MS.

[18] Teufel L. W., Chen H.-Y., Engles T. W. et al.: Optimization of Infill Drilling in Naturally-Fractured Tight Gas Reservoirs: Phase Ii, Final Report, Contract No. DOE-FC26-98FT40486. US DOE:Washington 2004. DOI: 10.2172/828437.

[19] Tokunaga H., Hise B. R.: A Method to Determine Optimum Well Spacing. Society of Petroleum Engineers 1966. DOI: 10.2118/1673-MS.

[20] Voneiff G. W., Cipolla C.: A New Approach to Large-Scale Infill Evaluations Applied to the Ozona (Canyon) Gas Sands. Paper SPE 35203 presented at the Permian Basin Oil and Gas Recovery Conference, Midland, Texas 27-29 March 1996. DOI: $10.2118 / 35203-\mathrm{MS}$.

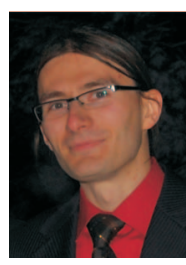

Krzysztof MIŁEK M.Sc., Eng.

Junior Scientist

Hydrocarbon Deposits and UGS Simulation

Oil and Gas Institute - National Research Institute

ul. Lubicz 25 A

31-503 Kraków

E-mail:krzysztof.milek@inig.pl 